\title{
ENGAGING WITH EDMODO TO TEACH ENGLISH WRITING OF NARRATIVE TEXTS TO EFL STUDENTS
}

\author{
Qismullah Yusuf, Yunisrina Qismullah Yusuf, \\ Nira Erdiana, Arif Rizky Pratama \\ Syiah Kuala University, Indonesia \\ E-mail: yunisrina.q.yusuf@unsyiah.ac.id
}

\begin{abstract}
This experimental research aimed to explore the effect of teaching English writing of narrative texts by using Edmodo learning media through blended learning on the tenth-grade students in one of the senior high schools in Banda Aceh, Indonesia. It further looks into the students' responses on the use of this media in learning English writing of narrative text. To study the development of the students' writing before and after using Edmodo learning media in the classroom, the writing tests were given to the students. The data were gained quantitatively and qualitatively. The quantitative data were collected from the pre-test, treatments for three class meetings and the post-test, while the qualitative data was collected through the open-ended questionnaire which was distributed to the students after the treatments were done. Statistical formulas were used to calculate the mean, standard deviation, and t-test for the students' pre-test and post-test scores. The hand coding and computer coding were used to analyze the data from the questionnaire. The results from the analysis of quantitative data showed that there was an improvement in students' writing of narrative texts; their scores improved from the pre-test to the posttest after treatments with Edmodo were done. Furthermore, the analysis of the questionnaire revealed a majority of positive responses from the students. Those who negatively responded towards the use of this online learning media said that it was due to the necessity of the Internet connection and computers, laptops or mobile phones to operate Edmodo. Not all students have the privilege of possessing such devises and the Internet quota can also be costly. Thus, they recommended the school to provide them with free access to the Internet and computers should learning by using this media is to be continued in the future.
\end{abstract}

Keywords: Blended learning, Edmodo, EFL students, English writing, narrative texts.

\section{Introduction}

Narrative texts and how to write them is taught to students in the senior high school level in Indonesia. This text tells a story that has happened (in the past) with the purpose of entertaining the readers. To be able to write a narrative text that is interesting and entertaining for readers, the writer must be creative in choosing ideas and stories. Nevertheless, as these students are English learners in a country that treats English as a foreign language (Sari \& Yusuf, 2009), problems in learning this language are plausible. The researchers observed a few senior high schools in Banda Aceh and found that in one of the schools, these students particularly faced the most problems in writing, especially in narrative texts. Their scores were found to be lower than the other students from the other senior high schools under observation. Thus, an experimental teaching to assist these students in improving their writing skills is deemed necessary to be conducted.

Based on the preliminary research data recorded through students' writing assignments, observations, and informal interviews with four teachers who teach English at the school, the researchers noted some problems that deal with their writing ability. Most of the students in this school had difficulties to get started to write in English and to develop their thoughts and 
Qismullah YUSUF, Yunisrina Qismullah YUSUF, Nira ERDIANA, Arif Rizky PRATAMA. Engaging with EDMODO to teach English writing of narrative texts to EFL students

\section{PROBLEMS \\ OF EDUCATION \\ IN THE $21^{\text {st }}$ CENTURY Vol. 76, No. 3, 2018 \\ 334}

ideas into a good paragraph of narrative text. They tended to spend much time to think about the content and how to organize their writing. Not only having problems with those writing aspects, they also had some problems with the other of writing aspects, especially the vocabulary aspect. It was still a struggle to almost all students. Besides vocabulary aspect, many grammar errors were also identified into their writing. Moreover, in the classroom observation during the learning process, the students were also seen to be passive in the classroom, most of them were silent in class and rarely asked for guidance and help from teachers or classmates.

Therefore, based on this situation, the researchers decided to implement a method which so far has never been applied in their process of teaching and learning writing in the classroom. The method provides the experience of using technology in combination with the classroom learning process. The use of technology in language learning in this era, specifically in writing, is no longer a new phenomenon. Technology has changed education, it becomes more simple without interruption time and place (Alonso, López, Manrique \& Viñes, 2005). Even though English teachers in Aceh, Indonesia, mostly have a low capacity for using ICT (Muslem, Yusuf \& Juliana, 2018), thus to encourage those who have the capacity and facility to use it is essential because using technology as an innovation in teaching is one way to improve the quality of student learning outcomes (Dudeney \& Hockly, 2007).

Innovation in learning provides experiences to teachers and students and using technology as a media of education is one of the ways. According to Tsou, Wang and Tzeng (2006), many countries that have used the technology spring positive effects on learning the language. In terms of writing, it is difficult to write without creativity. Accordingly, to increase creativity, encouraging students to become active by creating an attractive learning environment is vital in the classroom.

Among the current innovations in language learning is the use of Blended Learning (hereafter, BL). It is a learning method that can provide and create an attractive learning environment for students because it combines face-to-face learning with online teaching (Van Dam \& Andrade, 2005). Thorne (2003) further describes that BL gives an opportunity to capitalize on advances in innovation and technology provided by online teaching with the interactions that occur in traditional learning. BL can be used in all kinds of subject being taught in the classroom. As for teaching writing, Westwood (2008) claims that writing today does not have to be done merely on paper, but also in other media, such as Blogs (Silviyanti \& Yusuf, 2015), Quipper School (Kamarullah, Yusuf \& Meutia, 2016), Edmodo (Al-Naibi, Al-Jabri \& Al-Kalbani, 2018), among others.

This research focuses on the use of Edmodo in the BL method. Kongchan (2012) describes Edmodo as one of the technological developments for educational purposes and is believed to assist teachers in language classrooms. She further explains that this educational technology resembles Facebook, so it can provide a place for teachers, students, and even parents to make the most of the learning process. Moreover, Charoenwet and Christensen (2016) portray Edmodo as an internet-based learning management system (LMS) that presents a safe virtual classroom moderated by a teacher. It facilitates channels for students to communicate with the teacher and participate in class activities out of the classroom. This virtual classroom provides students the opportunities to share ideas, follow up with class assignments, and take quizzes. As for students, they can use Edmodo to not only interact with the teacher, but also with their classmates. In favor of teaching writing, Lara (2013) claims that Edmodo can cover up the lesser amount of time of studying in the classroom by continuing the lessons through this technology at home because students can access it anywhere and anytime. The learning process can still take place even if the students and teachers are already in their homes. 


\section{Literature Review}

\section{Blended Learning}

Blended learning or BL is a method that combines two ways in the learning process. According to Singh and Reed (2001), this learning is a program where more than one method is used with the aim of optimizing the learning process and learning outcomes. It is a combination of face to face learning and online teaching (Bonk \& Graham, 2005). BL is also called hybridization (Jacob, 2011). Consequently, Egbert and Hanson-Smith (1999) propose some characteristics of this method, which are:

- Learners have opportunities to interact socially and negotiate meaning.

- Learners have enough time and feedback.

- It is guided to attend mindfully to the learning process.

- Learners work in an atmosphere with an ideal stress/anxiety level.

A number of authors have also noted the advantages for teachers and students in using BL in the classroom. First, Spika (2002) finds that this method helps students to develop their project and time management skill in learning. This is because they are given the autonomy and flexibility to choose time and place outside of the classroom to complete their work and this freedom shapes their personal time management skills. Second, it provides experience to students in using technology in learning (Wesson, McKenzie \& Bangay, 2015) and allows them to communicate and collaborate outside the classroom (Joutsenvirta \& Myyry, 2010). This technology pushes them to be more active and engaged in the lessons they are learning because they can do their own reading and develop their knowledge linked to real life cases. Finally, Fakhir (2015) states it makes teachers more effective in using technology and has a greater potential in teaching. The development of technology has made a paradigm change in learning where teachers are enforced to upsurge their understanding on how students learn nowadays. Since media is now fundamental either in students' or teachers' daily lives, therefore, it is essential for teachers to suit their teaching methods by developing their learning devices with the present teaching and learning environment. And so, it could be concluded that BL is useful if it is implemented in the learning process because it essentially provides innovation and new experiences for both teachers and students in using technology for teaching and learning.

\section{Edmodo}

Edmodo is owned, created, and funded by Nicolas Borg and Jeff O'Hara in San Mateo, California, in 2008. Working in an educational environment, Borg and O'Hara saw that there were problems in the learning process and teachers' difficulty in utilizing technology to connect with students. Hence, Edmodo was created. Today, it is a popular web-based learning site that is used as a medium of learning. It is a private micro blogging service which provides a secure and free learning platform (Haygood, Garner \& Johnson, 2012). According to Kongchan (2013), it is among the top teaching and learning website that provides innovation and creativity in the learning process. It has been popular for many educational institutions because of the features that it offers (Delacruz, 2013).

Besides providing facilities for teachers and students, parents can also connect to their children in the learning process. It is made much like Facebook and comfortable to use, but for the purpose of learning through the media (Kongchan, 2013). The website for Edmodo is available at www.edmodo.com.

The Edmodo website is constantly developed and so provides innovation and creativity in the process of teaching and learning (Kongchan, 2012). There are a number of advantages of using Edmodo in the teaching and learning process. Among them are students can upload homework assignments, take quizzes, polls and receive grades and feedback and suggestions from teachers in real time. Both students and teachers can share documents and digital media 
Qismullah YUSUF, Yunisrina Qismullah YUSUF, Nira ERDIANA, Arif Rizky PRATAMA. Engaging with EDMODO to teach English writing of narrative texts to EFL students

\section{PROBLEMS \\ OF EDUCATION \\ IN THE $21^{\text {st }}$ CENTURY Vol. 76, No. 3, 2018 \\ 336}

online and further make connections with those not just in the same classroom but also with others from different schools, states, or cultures. Al-Khatiri (2015, p. 199) appealingly find Edmodo that "while the students can benefit from the personal communication brought in by classroom and face-to-face interaction, the collaborative environment provided by Edmodo ensures that knowledge is no longer contained in places defined by geography and can be shared and viewed transparently". In addition, parents can be involved by viewing their children's work and grades and keep in touch with the teachers. And thus, this website provides a multitude of community resources and connections teachers can make not just with other teachers, but also with parents. Finally, this website is also secure because it is a closed network and can also be used with mobile devices.

Some studies have been conducted on the use of Edmodo to assist students in writing, especially students in the EFL context. A research by Janpho, Chaeturat, Multa, Harnburut and Kwangsawad (2014) used an experimental research to investigate the application of Edmodo in assisting the high school students' writing skills in Thailand. They revealed that Edmodo did not only assist the students in improving their writing skills, but it also increased their motivation to write in English. Studies in Indonesia such as by Noviana, Rufinus and Bunau (2015) explored the effective use of Edmodo in writing a narrative text to tenth grade students in one of the senior high schools in Sungai Kakap. The results of this research also showed improvement of the students' writing skills after this technology was used in teaching writing. Similar results were also found by Purnawarman, Susilawati, and Sudayana (2016) who looked at the use of Edmodo in teaching writing in the BL setting for the eleventh-grade students of a private senior high school in Cimahi. The results obtained from the research were that the students become more active in learning, able to work equally well in the group and the quality of the student's work became better than before the application of this technology.

Yet, among the advantages, there are also challenges in using Edmodo in the teaching and learning process. First of all, using websites and technologies in the teaching and learning process requires good Internet connection and high abilities of teachers to operate and teach them to the students (Grosseck, 2009). Facing slow speed connections of the Internet can also hamper effective implementation of the online learning (Motiwalla, 2007; Stockwell, 2008). These facilities are also costly; starting from availability of the media and intensive teacher training to use them effectively for teaching are the budgetary glitches that many school face (Almaini, 2013; Barnawi, 2009). When these are not made available by the school, some teachers who weigh them on students (e.g. have to buy the Internet quota, computer, laptops, mobile phones, etc.) become problems, especially those who come from low-income families (Stroud, 2010). Students who are not used to experiencing online utility may also find it difficult to adapt to the online learning introduced by the teachers and to have them grasp the skill may take time (Alebaikan \& Troudi, 2010). And so, to make use of online learning, teachers must make sure that the school provides the students with this ability, and or the students themselves are willing to go the extra mile to experience the online teaching and learning.

\section{Problem of Research}

For the reason that Edmodo has shown success in previous research, the researchers in this study would also like to examine its effects in teaching writing for the senior high school students in the English class under study for this research. Hence, the research questions to be answered are:

1.Does an Edmodo learning medium improve students' English writing skill in the narrative texts?

2. What are the students' opinions on the use of an Edmodo learning medium in learning English writing on narrative texts?

Based on the questions formulated above, especially for research question number one, the researchers further formulated the following hypotheses: 
- $\mathrm{H}_{1}$ : There is an improvement on students' English writing narrative texts after using Edmodo learning media.

- $\mathrm{H}_{2}$ : There is no significant improvement on students' English writing narrative texts after using Edmodo learning media.

The result of this research is expected to add knowledge on the use of an Edmodo learning medium in the classroom, especially in the English teaching and learning process. Since technology is developing rapidly in this era, Edmodo is hoped to become one of the interactive learning media to be used by English teachers as one of the new ways to teach English, by overcoming its pros and cons of implementation in the classroom.

\section{Methodology of Research}

\section{General Background}

The methodology used in this research was quantitative and qualitative. Arikunto (2006) states that quantitative research is a kind of research that requires the use of numbers: ranging from data collection, data interpretation and data appearance of the results. In this research, the researchers seek to know if there was any improvement in students' writing narrative text by using Edmodo learning media, and also to apprehend the responses of the students on using this learning media after the treatment was conducted. Accordingly, to answer the first research question, an experimental teaching was employed by utilizing the one group pre-test and posttest design. This design includes one group or class of students that comprised a pre-test in one meeting, treatment in three meetings and a post-test in one meeting (Hatch \& Lazaraton, 1991).

Figure 1 displays an overview of the research process.

$$
\text { PRE-TEST } \longrightarrow \text { TREATMENT } \longrightarrow \text { POST-TEST }
$$

\section{Figure 1: One group pre-test - post-test design (Source: Hatch \& Lazaraton, 1991).}

In this design, a pre-test was given before conducting the treatments and a post-test was given after the treatments to the students. Meanwhile, the qualitative approach was used for the open-ended questionnaire that was involved in collecting data to answer the second research question. The researchers had conducted this research for five meetings; one meeting for the pre-test, three meetings for treatments, and the last remaining meeting for the post-test. This subject was taught four hours a week or $4 \times 45$ minutes at the school under research, with a schedule of twice a week ( $2 \times 45)$ minutes for each meeting).

\section{Sample}

The population in this research was the first-grade high school students of SMAN 11, Banda Aceh, Indonesia. There were seven classes in this grade that consist of 23 to 25 students in each class. The researchers chose one class randomly by writing all seven classes in a paper, putting them all in a box, then selecting one as a sample of this research. Finally, class X2 that consists of 23 students was selected the sample of this research. Referring to Latham (2007), random selection of the sample gives equal opportunity to every member of the population. The school does not provide computers or free Internet access to the students, therefore, prior to conducting this research; the researchers had asked consent from both students and their parents that they would need to provide laptops or computers at home and the Internet to run this research for 3 weeks. Fortunately, all parents each had a laptop at home and every student had a mobile phone, except for three students. Nevertheless, after negotiation, their friends who 
Qismullah YUSUF, Yunisrina Qismullah YUSUF, Nira ERDIANA, Arif Rizky PRATAMA. Engaging with EDMODO to teach English writing of narrative texts to EFL students

\author{
PROBLEMS \\ OF EDUCATION \\ IN THE $21^{\text {st }}$ CENTURY \\ Vol. 76, No. 3, 2018 \\ 338 had the facilities were willing to share theirs with these students because they all wanted to be \\ part of the experiment willingly. After they had given consent, the research was carried out.
}

\title{
Instrument
}

\section{The Writing Tests}

There are two kinds of tests used in this research, the writing test before the treatment is implemented (i.e. pre-test) and the writing test after the treatment is implemented (i.e. posttest). The fourth author of this paper was the teacher in conducting this experimental research. At the beginning of this research, students were given a pre-test to find out the initial state of their writing ability in narrative text. In the process of the pre-test and the post-test, students were asked to write a short narrative text of about three paragraphs of a legendary person. The legend must be about someone who is an inspiration to them. After the pre-test in the first meeting, students were introduced to the Edmodo to assist them in learning narrative texts. These treatments were done for three meetings. Meanwhile, the post-test was given after the treatments to evaluate their writing ability improvement. It was used to examine the effects of the treatment. The evaluation of the students' writing focus on the aspects of writing, which are: organization, content, grammar, vocabulary, and mechanic. The results of the pre-test and posttest were used to study the differences before and after the treatments on implementing Edmodo to teach English writing of narrative texts to the students were done.

\section{Questionnaire}

The questionnaire given after the post-test was in the form of open-ended questions. Foddy (1993) asserts that open-ended questions give freedom to respondents to give their opinions; meanwhile the close-ended questions provide fewer response options. And so, the researchers chose the open-ended questionnaire to obtain better responses from the students about the application of Edmodo in the teaching and learning of narrative texts. The following questions were asked:

1. What do you think about the use of Edmodo in learning to write a narrative text?

2. If the use of Edmodo continues, do you agree? Why or why not?

\section{Procedure}

English was taught four hours a week or $4 \times 45$ minutes at the school under study, with a schedule of twice a week ( $2 \times 45$ minutes for each meeting). To collect data from the two tests and questionnaire, the following steps were taken.

Pre-test

On the first meeting, the researchers asked the students to write a narrative text about a legendary person. They were to write a story of about three paragraphs or a minimum of 150 words and they were free to choose the legend that they adore and inspire them. The time given was $2 \times 45$ minutes. The story must be original; not a copy paste from the internet or other people's work.

\section{Treatments}

After giving the pre-test, the researchers started using Edmodo in teaching writing a narrative text on the next meeting. Treatments were conducted over three consecutive meetings. The researchers began the first day of treatment by explaining the definition of narrative text 
and providing examples. The aspects of writing, which are writing aspects of organization, content, grammar, vocabulary, and mechanic, were taught to the students. The criteria of good writing in these aspects based on Brown (2004) were also taught. Near the end of the first meeting, the students were given an exercise to help them identify good and bad writing by working in pairs. At the end of the meeting, the researchers explained about their plan at the next meeting, in which the students would be introduced to Edmodo.

On the second meeting, the researchers began the learning process by introducing the students to the Edmodo website. After making sure that students had understood on how to use the website, they asked the students to write a narrative text about a legendary person of their interests and to post it on their Edmodo class group. Students were asked individually to write their story as much as three paragraphs or about 150 words. They were to also give comments and suggestions to every essay of their classmates, with at least one post per student for one essay. The comments and suggestions should focus around the writing aspects of organization, content, grammar, vocabulary, and mechanic. It is expected that by doing peer-correction, students can share ideas, thoughts and learn from each other. The researchers monitored every activity of the students to ensure that every student participated in this activity.

On the third meeting, the researchers chose three essays from the students to discuss in class. The discussion revolved around every comment and suggestion made by the students on the essays. For the issues that needed further clarification from the researchers, these were done then during this face-to-face interaction. For example, a student had commented on an incorrect use of grammar by another student on her writing, and this was justified and clarified by the researchers. Near the end of the meeting, they asked the students to write another essay on a different legendary person of their choice and to post it again in their Edmodo class group. Every student was to evaluate their writing sensibly based on the comments and suggestions given by their classmates in their previous post. Again, they were to also give comments and suggestions to every essay of their classmates, with at least one post per student for one essay.

\section{Post-test}

Similar to the pre-test, students were asked to write a narrative text about a legendary person, but he or she must be different from their essays during the pre-test and treatments. Their story was of about three paragraphs or a minimum of 150 words. The time given was $2 \times 45$ minutes and the story must be original; not a copy paste from the internet or other people's work.

\section{Questionnaire}

The questionnaire was given after the whole process was complete. Students were to write their answers down on the questionnaire paper and the time given to complete it was 15 minutes.

\section{Data Analysis}

\section{Tests}

In evaluating the students' writing, several aspects were considered in the assessment process. The language assessment and scoring system focused on the aspects of writing: organization, content, grammar, vocabulary and mechanic (Brown, 2004), as shown in Table 1. 
Qismullah YUSUF, Yunisrina Qismullah YUSUF, Nira ERDIANA, Arif Rizky PRATAMA. Engaging with EDMODO to teach English writing of narrative texts to EFL students

PROBLEMS

OF EDUCATION

IN THE $21^{\text {st }}$ CENTURY

Vol. 76, No. 3, 2018

340

Table 1. The Writing Scoring Scale (source: Brown, 2004, p. 242).

\begin{tabular}{|c|c|c|}
\hline Aspect & Score & Criteria \\
\hline \multirow{8}{*}{$\begin{array}{l}\text { Organiza- } \\
\text { tion }\end{array}$} & $\begin{array}{l}20-18 \\
\text { Excellent to good }\end{array}$ & $\begin{array}{l}\text { Appropriate title, topic is stated, leads to body, transition expression used, ar- } \\
\text { rangement of material show plan, supporting evidence show the generalization. }\end{array}$ \\
\hline & $\begin{array}{l}17-15 \\
\text { Good to adequate }\end{array}$ & $\begin{array}{l}\text { Adequate title, body of essay is acceptable, but some evidence may be lacking, } \\
\text { some ideas aren't fully developed, sequence is logical but transitional expres- } \\
\text { sion may be absent or misused. }\end{array}$ \\
\hline & $14-12$ & Problems with the order of ideas in the body, generalization may not be fully \\
\hline & Adequate to fair & supported by the evidence given, problem of organization interfere. \\
\hline & $11-6$ & Minimally recognizable introduction, organization can barely be seen, severe \\
\hline & Fair to poor & problems with ordering of ideas, inadequate effort at organization. \\
\hline & & No apparent organization of body, writer has not made any effort to organization \\
\hline & Very poor & the composition. \\
\hline \multirow{5}{*}{ Content } & $\begin{array}{l}20-18 \\
\text { Excellent to good }\end{array}$ & $\begin{array}{l}\text { Essay addresses the topic, the ideas are concrete and thoroughly developed, } \\
\text { and essay reflects thought. }\end{array}$ \\
\hline & $\begin{array}{l}17-15 \\
\text { Good to adequate }\end{array}$ & $\begin{array}{l}\text { Essay addresses the issues but misses some points, ideas could be more fully } \\
\text { developed. }\end{array}$ \\
\hline & $\begin{array}{l}\text { 14-12 } \\
\text { Adequate to fair }\end{array}$ & $\begin{array}{l}\text { Development of ideas not complete or essay is somewhat off the topic, para- } \\
\text { graphs aren't divided exactly right. }\end{array}$ \\
\hline & $\begin{array}{l}11-6 \\
\text { Fair to poor }\end{array}$ & $\begin{array}{l}\text { Ideas incomplete, essay does not reflect carefully thinking or was hurriedly writ- } \\
\text { ten, inadequate effort in area of content. }\end{array}$ \\
\hline & $\begin{array}{l}5-1 \\
\text { Very poor }\end{array}$ & $\begin{array}{l}\text { Essay is completely inadequate, no apparent effort to consider the topic care- } \\
\text { fully. }\end{array}$ \\
\hline \multirow{6}{*}{ Grammar } & $\begin{array}{l}20-18 \\
\text { Excellent to good }\end{array}$ & $\begin{array}{l}\text { Correct of preposition, modal, article, word form, and tense using, no fragment } \\
\text { or run on sentences. }\end{array}$ \\
\hline & $\begin{array}{l}17-15 \\
\text { Good to adequate }\end{array}$ & $\begin{array}{l}\text { Some grammar problems do not influence communication and no fragments or } \\
\text { run on sentences. }\end{array}$ \\
\hline & $14-12$ & Ideas are getting through to the reader, grammar problems are apparent and \\
\hline & Adequate to fair & have negative effort on communication, run on sentences. \\
\hline & $\begin{array}{l}11-6 \\
\text { Fair to poor }\end{array}$ & $\begin{array}{l}\text { Numerous serious grammar problems interfere with communication of writer's } \\
\text { ideas, grammar review of some areas is clearly needed, difficult to read sen- } \\
\text { tences. }\end{array}$ \\
\hline & $\begin{array}{l}5-1 \\
\text { Very poor }\end{array}$ & $\begin{array}{l}\text { Severe grammar problems interfere greatly with the message, reader cannot } \\
\text { understand what the writer was trying to say, unintelligible sentence structure. }\end{array}$ \\
\hline \multirow{6}{*}{ Vocabulary } & $\begin{array}{l}20-18 \\
\text { Excellent to good }\end{array}$ & Precise vocabulary usage, use of parallel structure, concise, register good. \\
\hline & $17-15$ & \\
\hline & Good to adequate & Attempts variety, good vocabulary, not wordy, style fairly concise. \\
\hline & $\begin{array}{l}\text { 14-12 } \\
\text { Adequate to fair }\end{array}$ & Some vocabulary misused, lacks awareness of register, may be too wordy. \\
\hline & $\begin{array}{l}\text { 11-6 } \\
\text { Fair to poor }\end{array}$ & Poor expression of ideas, problems in vocabulary, lacks variety of structure. \\
\hline & V-1 & Inappropriate use of vocabulary, no sentence variety. \\
\hline \multirow{6}{*}{ Mechanics } & Excellent to good & All needed capitals, paragraph intended, punctuation and spelling very neat. \\
\hline & $17-15$ & \\
\hline & Good to adequate & Some problems with punctuation, occasionally spelling errors. \\
\hline & $\begin{array}{l}\text { 14-12 } \\
\text { Adequate to fair }\end{array}$ & Spelling problems distract the reader, punctuation errors interfere with ideas. \\
\hline & $\begin{array}{l}11-6 \\
\text { Fair to poor }\end{array}$ & Part of essay not legible, errors in sentence punctuation. \\
\hline & $\begin{array}{l}5-1 \\
\text { Very poor }\end{array}$ & $\begin{array}{l}\text { Complete disregard for English writing convention, obvious capital missing, } \\
\text { severe spelling problems. }\end{array}$ \\
\hline
\end{tabular}


From Table 1, the researchers conclude that writing is not only expressing ideas and messages in written form, but writers must also pay attention to the techniques of writing to produce good writing. Those aspects in Table 1 must be mastered to produce good writing by the students. First is the content that deals with a thesis statement, related ideas, development of ideas through personal experience, illustration, facts, and opinion. Second is the organization that covers the effectiveness of introduction and logical sequence of ideas. Third is the syntax which includes sentence structure. Fourth is vocabulary which includes the effective word, idiom choice, and usage, and word form mastery. Fifth is mechanics that consists of spelling, punctuation, citation of reference (if applicable), neatness and appearance.

After scoring the students' writing of narrative texts, the researchers used the statistical formulas to calculate the mean score (Heaton, 1988), standard deviation (Ary, Jacobs, Razavieh \& Sorensen, 2009), and t-test (Ary, Jacobs, Razavieh \& Sorensen, 2009). These formulas were used to determine whether or not there was any improvement from pre-test to post-test. Finally, to examine the hypothesis, the result of statistical analysis above was compared to the limit score in the measurement table of t-scores. For the significance, the significant value of $5 \%$ $(\alpha=.05)$ is used.

\section{Questionnaire}

The hand coding and computer coding were used to analyze the data from the questionnaire. Hand coding is also called code sheet which contains some questions and their responses (Riffe, Lacy \& Fico, 2005). Afterwards, the data were transferred to Microsoft Exel and the responses were classified into several categories to determine the most to the least responses from the students. The categories are Interesting (I), Quite Interesting (Q), Ordinary (O) and Not Interesting (N) for the first question, and Agree (A), Disagree (D) and Partially (P) for the second question. Finally, these categories were counted to obtain the percentage for each category of the students' responses. A simple percentage formula was used to do so (Chambliss \& Schutt, 2013).

\section{Results of Research}

\section{Students'Scores in the Pre-test and Post-test}

Based on the calculations of the students' scores in the pre-test and post-test, the results showed that almost all students increased their scores of writing narrative texts in the post-test. Although there were still some students who obtained scores below the standard score that is 70 , thus the treatment of teaching a narrative text by using Edmodo combined with learning in the classroom made a positive impact on the students.

In the pre-test, the sum of the score from whole writing aspects of 23 students is 1606 , while the sum of the score in the post-test is 1818. In getting the mean score of both tests, the sum of the score in pre-test and post-test were divided by the number of students. As a result, the mean score of pre-test is 70.333, whereas that of post-test is 79.043 . Hence, the difference between the two mean scores is 8.71 . It is clear that the mean score of post-test increased as compared to the pre-test, as illustrated in Figure 2. This indicates that the students' narrative text writing had improved after using Edmodo. 
Qismullah YUSUF, Yunisrina Qismullah YUSUF, Nira ERDIANA, Arif Rizky PRATAMA. Engaging with EDMODO to teach English writing of narrative texts to EFL students

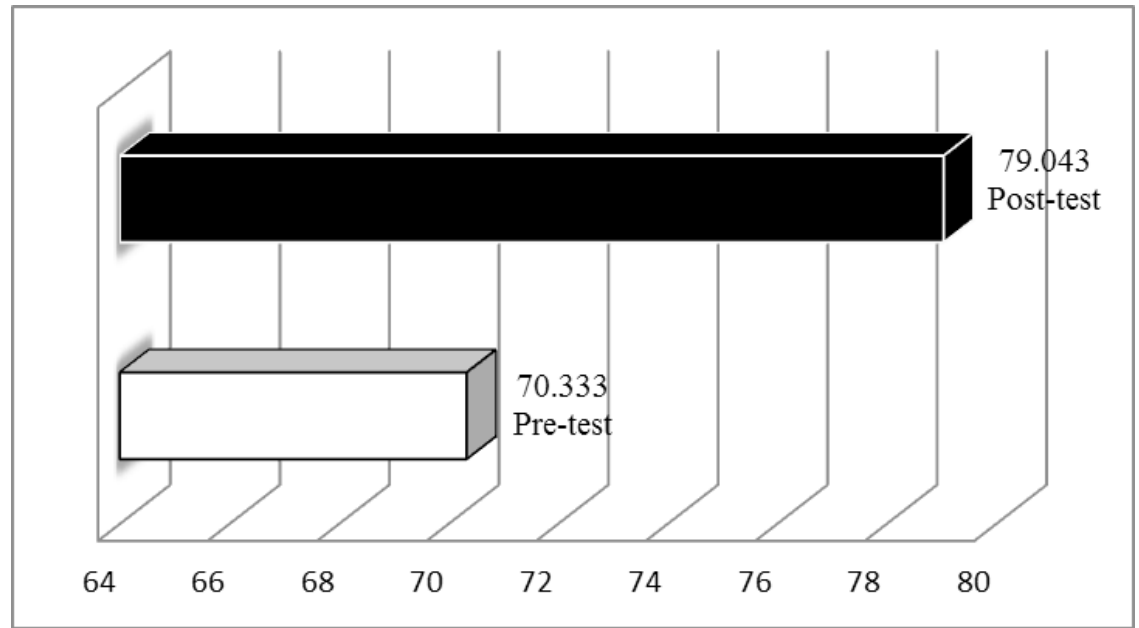

Figure 2: The mean scores of pre-test and post-test.

The standard deviation is further calculated after comparing the students' scores in the pre-test and post-test. The deviation score is considered negative if the score is below the mean score, and positive if the score is above the mean score. From the calculation, it was found that the dispersal of students' score is 10.06; that means that the mean score is higher than the deviation scores, so this study shows a positive result.

The hypothesis of this research was analyzed by using the t-test. The result of t-score is 4.40 , and the t-score is referred to the critical value of t-table at the level of significance $\alpha$ $=.05$ with the degree of freedom $(\mathrm{df})=23-1$, which is 2.819 . Since the $\mathrm{t}$-score is higher than t-table $(4.40>2.819)$, thus the alternative hypothesis or $\mathrm{H}_{1}$ is accepted. It indicates that there is a significant increase of the students' writing scores after they were treated with Edmodo in teaching to write narrative text.

\section{Results of Each Writing Comprehension Aspect in Pre-test and Post-test}

The interval used to measure the students' capability in writing narrative text deals with the organization, content, grammar, vocabulary, and mechanic. To see the students' progress in both pre-test and post-test for each aspect of writing in the narrative text, the data in detail can be seen in Figure 3. 


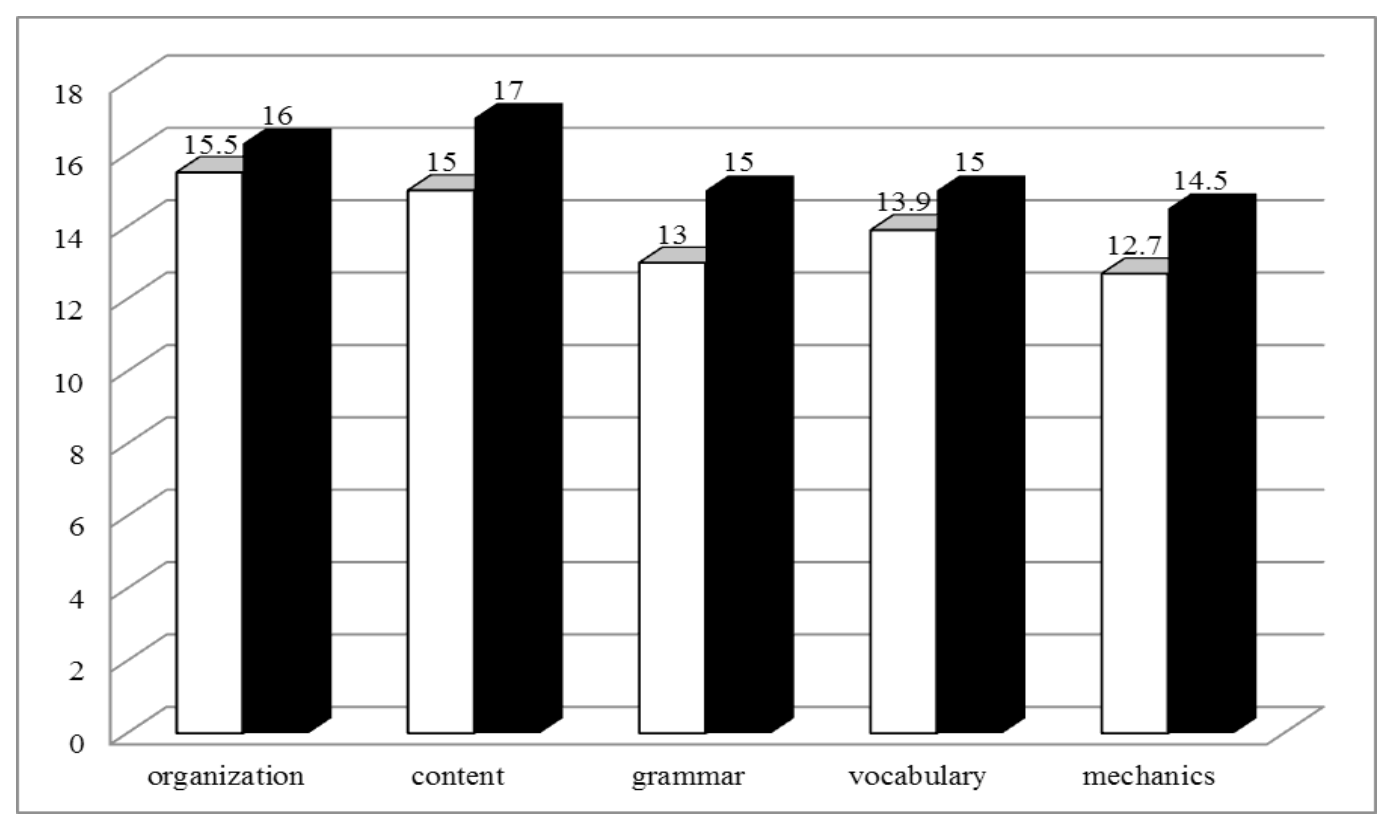

$\mid$\begin{tabular}{l} 
PROBLEMS \\
OF EDUCATION \\
IN THE 21 ${ }^{\text {st }}$ CENTURY \\
Vol. 76, No. 3, 2018 \\
\hline 343
\end{tabular}

Note: White $=$ pre-test, Black $=$ post-test

Figure 3: The mean score of each writing comprehension aspect in both tests.

Based on Figure 3, there are upward movements in each mean score of the aspect being scored. This means that all of the mean scores increased from the pre-test to the post-test. The largest increase is in the content aspect and the grammar aspect. The content aspect goes up 2.00 points from the pre-test to the post-test, whereas, the grammar aspect increases 2.00 points as well. The other two aspects, vocabulary and mechanic also show improvements by reaching the progress of 1.1 points in vocabulary and 1.8 points in mechanic. Organization increases 0.5 points from the pre-test to the post-test.

\section{Students'Responses toward Questionnaire}

Two questions were asked to know the opinions of students from the application of Edmodo in the teaching and learning process of writing narrative text. Table 2 presents the responses of the students to the first question. 
Qismullah YUSUF, Yunisrina Qismullah YUSUF, Nira ERDIANA, Arif Rizky PRATAMA. Engaging with EDMODO to teach English writing of narrative texts to EFL students

PROBLEMS

OF EDUCATION IN THE $21^{\text {st }}$ CENTURY Vol. 76, No. 3, 2018

344

Table 2. Students' responses toward the first questionnaire item.

\begin{tabular}{lll}
\hline $\begin{array}{l}\text { Students' } \\
\text { codes }\end{array}$ & $\begin{array}{l}\text { Responses to the question: "What do you think about the use of Edmodo in } \\
\text { learning writing narrative texts?" }\end{array}$ & Category \\
\hline SA & Interesting, because the learning process is different & Interesting \\
\hline M & I don't really understand because of the new way & Ordinary \\
\hline S & Interesting because studying with the Internet & Interesting \\
\hline SN & Different from the way that has been used to learn & Interesting \\
\hline DLK & Interesting but a bit troublesome because of using laptop & Ordinary \\
\hline UT & Exciting unlike the usual & Interesting \\
\hline SU & I can ask for solutions in group and others will help & Interesting \\
\hline NA & Initially difficult, but after I understand, it became exciting & Interesting \\
\hline NLH & Must go to the cafe to do the task & Not Interesting \\
\hline FS & Exciting, but must have an Internet network & Quite Interesting \\
\hline JR & Learning is cool because of using the Internet & Interesting \\
\hline AM & Learning writing was never like this, this is fun & Interesting \\
\hline AS & If I don't understand about something, I can ask directly to the Edmodo group & Interesting \\
\hline FN & The problem is doing the task on a friend's laptop & Quite Interesting \\
\hline NS & Quite interesting, because I can work at home & Quite Interesting \\
\hline RZ & Learning online is cool, the teacher can also provide comments & Interesting \\
\hline NR & Some friends are less active in the group, so all friends should be active & Quite Interesting \\
\hline SA & If all the teachers teach using the Internet, it would be cool & Interesting \\
\hline DF & Learning with Edmodo is like using Facebook & Interesting \\
\hline DUP & Mr. ARP is the first teacher who uses this way of learning, cool sir & Interesting \\
\hline SS & Learning to write becomes fun, not boring & Interesting \\
\hline FNN & Complicated, because I use my parents' laptop while doing the task & Not Interesting \\
\hline NS & Now we have a study group on the Internet & Interesting \\
\hline & & \\
\hline
\end{tabular}

From Table 2, the categories were calculated for percentage, which is by dividing the frequency of cases in a particular category by the total number of cases and multiplying by 100 . The result is as shown in Table 3.

Table 3. Students' responses to the first questionnaire item in percentage.

\begin{tabular}{llll}
\hline No. & Category & Frequency & Percentage (\%) \\
\hline 1 & Interesting & 15 & 65.2 \\
\hline 2 & Quite Interesting & 4 & 17.4 \\
\hline 3 & Ordinary/Neutral & 2 & 8.7 \\
\hline 4 & Not Interesting & 2 & 8.7 \\
\hline Total & & 23 & 100 \\
\hline
\end{tabular}

Based on Table 3, $65.2 \%$ of students say that Edmodo learning media is interesting, $17.4 \%$ find it quite interesting, $8.7 \%$ find it ordinary or neutral and another $8.7 \%$ say that it is not interesting. This indicates that a majority of students responded positively to the use 
of Edmodo in the teaching and learning process because it is something new to them, so it is interesting and exciting, provides a platform for discussion with all of their classmates and

PROBLEMS

OF EDUCATION

IN THE $21^{\text {st }}$ CENTURY

Vol. 76, No. 3, 2018

345 teacher, and the teacher can also respond to all of their inquiries through this platform before the meet up for the face-to-face meeting in the classroom. Nevertheless, those who do not find this method to be interesting is because the Internet connection is essential to use Edmodo and either a laptop, mobile phone or computer is needed to perform all tasks through this website.

Furthermore, Table 4 displays the responses of the students towards the second question.

Table 4. Students' response to the second questionnaire item.

\begin{tabular}{lll}
\hline Students' codes & $\begin{array}{l}\text { Responses to the question: "If the use of Edmodo continues, do you } \\
\text { agree?" }\end{array}$ & Category \\
\hline SA & Agree, Sir, for a better learning system & $\mathrm{A}$ \\
\hline M & I want to learn English always like this & $\mathrm{A}$ \\
\hline S & Bothersome because I have to bring a laptop & $\mathrm{D}$ \\
\hline SN & It is different from previous methods, so I want this to continue & $\mathrm{A}$ \\
\hline DLK & If I don't have to bring a laptop, I agree & $\mathrm{P}$ \\
\hline UT & Agree, Sir, learning is not boring & $\mathrm{A}$ \\
\hline SU & If the Internet network is smooth, I agree & $\mathrm{P}$ \\
\hline NA & Agree, because it is interesting & $\mathrm{A}$ \\
\hline NLH & Disagree, need the Internet always & $\mathrm{D}$ \\
\hline FS & It uses my Internet quota, it is costly, disagree & $\mathrm{D}$ \\
\hline JR & Agree, Sir, if the school gives free Internet connection & $\mathrm{P}$ \\
\hline AM & Hopefully this continues & $\mathrm{A}$ \\
\hline AS & I want this to continue & $\mathrm{A}$ \\
\hline FN & Agree, as long as we can study in groups through the website \\
\hline NS & Agree, it is exciting & $\mathrm{A}$ \\
\hline RZ & Hopefully we can later learn like this again & $\mathrm{A}$ \\
\hline NR & Continue, so we can be more active in learning & $\mathrm{A}$ \\
\hline SA & Agree, Sir, it is interesting & $\mathrm{A}$ \\
\hline DF & Agree, it is fun & $\mathrm{A}$ \\
\hline DUP & Agree, Sir, it is interesting learning like this & $\mathrm{A}$ \\
\hline SS & Agree, if we use school computers & $\mathrm{A}$ \\
\hline FNN & Agree, if we use school computers & $\mathrm{P}$ \\
\hline NS & Agree, if the school provide the Internet and computers & $\mathrm{P}$ \\
\hline & & $\mathrm{P}$ \\
\hline
\end{tabular}

From Table 4, the categories were calculated for percentage, and the results are shown in Table 5.

Table 5. Students' responses to the second question in percentage.

\begin{tabular}{llll}
\hline No. & Category & Frequency & Percentage $(\%)$ \\
\hline 1 & Agree & 14 & 60.9 \\
\hline 2 & Disagree & 3 & 13 \\
\hline 3 & Partially & 6 & 26.1 \\
\hline Total & & 23 & 100 \\
\hline
\end{tabular}

From Table 5, it shows that $60.9 \%$ of students said they agree if Edmodo is continued in the future, $26.1 \%$ partially agree to its continuation and $13 \%$ say they disagree. Again, those students who agree alleged that this media is fun, interesting and made all of the students active in the process or learning through Edmodo. Similarly, students who partially agree or disagree 
Qismullah YUSUF, Yunisrina Qismullah YUSUF, Nira ERDIANA, Arif Rizky PRATAMA. Engaging with EDMODO to teach English writing of narrative texts to EFL students

\author{
PROBLEMS \\ OF EDUCATION \\ IN THE $21^{\text {st }}$ CENTURY \\ Vol. 76, No. 3, 2018 \\ 346 to its continuation is largely caused by the use of the Internet and media to operate it (e.g. \\ laptop, computer, mobile phones, etc.). For students who partially agree, they also recommend \\ that the school provides them with free Internet connection and computers to ease them in using \\ Edmodo for learning.
}

\title{
Discussion
}

Having assessed, calculated, and completed this research, the researchers got the results in which there were not only an improvement toward students' writing of narrative texts, but also positive responses from students in using Edmodo for their learning. Furthermore, by using Edmodo, peer corrections were performed by the students outside of the classroom hours. The discussion forum provided by this website for the class had enabled the students and the teacher to ask questions to each other, provide responses to each other, give comments, suggestions and even share knowledge anywhere and anytime online. The learning process continues outside of class and this progression can make up for the time that is not enough in the classroom (Lara, 2013).

The use of Edmodo in learning narrative text is further viewed to give the students new insights and experience in learning. They claim to be more active in asking and responding to problems faced in the learning process through the discussion forum provided by Edmodo and this process helped them in seeking for solutions to their writing difficulties. By the same token, previous studies by Noviana, Rufinus and Bunau (2015) and Purnawarman, Susilawati, and Sudayana (2016) also found Edmodo do activate students to be better in learning, to work equally well in groups and improve the quality of their work. Similar to the study by Janpho, Chaeturat, Multa, Harnburut and Kwangsawad (2014), a majority of students in this study were also found to be more motivated in the learning process because they find Edmodo to be interesting, fun and a new way of learning. They enjoy the fact that they are able to ask questions in their class group and their friends and teacher provide responses so that solutions for every problem posed in the group can be resolved. Should it not, then they can continue the discussion during the next classroom meeting in school.

However, the results from the questionnaire have also revealed some setback in using Edmodo to teach and learn writing of narrative text. The main problems were the requirement of the Internet and computers to carry out the teaching and learning process. Even though the students and their parents have given consent to participate in this research for three weeks, there were students who find that the need of the Internet and computers could become troublesome since to use the Internet, they would need to buy the Internet quota, and for those who did not have computers or laptops (i.e. three students in this study) were tiresome especially if the task was conducted near the due date. These setbacks have been earlier discussed by Almaini (2013) that facilities to use technology in the classroom are indeed pricey. Therefore, any school that intends to make use of technology to increase innovation and effectiveness in the teaching and learning process, they should be ready with budgets to assist the teachers and students with facilities and knowledge on technology use (Barnawi, 2009). In the meantime, this is the problem that most teachers in Indonesia face today: cost, lack or insufficient competency in using ICT due to lack of training provided by the school and inadequate support from the school still exist (Silviyanti \& Yusuf, 2015). Since various studies have found that the use of multimedia in English language can increase students' interest in learning (Silviyanti, 2014), therefore the government is recommended to put priority on the financial plan for the public schools to use technology in the learning and teaching process, such as equipping free internet access and computers for the teachers and students to use in the school ground. Providing the teachers with sufficient training to run the technology should also be part of the plan. 


\section{Conclusions}

The use of Edmodo learning media to teach writing narrative text to students resulted positive impacts. The students initially had difficulty in writing narrative text in some aspects of writing, such as organization, content, grammar, vocabulary and mechanic. After doing the treatment, the students could write better narrative texts. These can be seen from the post-test results that are higher than the pre-test results, in which the mean score of pre-test was 70.333, meanwhile the mean score of post-test was 79.043. Referring to the statistical calculation of $\mathrm{t}$-test score, the result of t-test is higher than t-table which is $4.40>2.819$. As a result, the use of Edmodo learning media could improve the students' writing of narrative text in this research.

This research has proven that Edmodo is a media that does support the learning process. It provides solution to some problems especially in teaching writing to EFL students that emerge on a daily learning process. It assisted the teacher to manage the learning process and activate students to work enthusiastically either individually and in groups. Moreover, it provides convenience in communication for the teacher, students, and parents in the teaching and learning process.

To end with, the researchers also acknowledge the remaining gaps of this research, where the experiment of using Edmodo in teaching English writing to EFL students was only limited to one class. It focused on only one genre of writing text, and the responses from the students on Edmodo were extracted from a simple open-ended questionnaire. Additionally, the validity of the post contents or comments by students in Edmodo (i.e. students who post on behalf of their peers) was also not deeply investigated in this research. Hence, in the future, it is recommended that researchers cover more classes to do the experiment, employ more genres of texts and perhaps use in depth interviews to disclose more advantages and disadvantages in its implementation. By doing so, more information can be gained to have stronger inference on the use of technology in EFL classrooms.

\section{References}

Arikunto, S. (2006). Prosedur penelitian sebagai suatu pendekatan praktek [The research procedure as a practical approach]. Jakarta: Rineka Cipta.

Ary, D., Jacobs, L. C., Razavieh, A., \& Sorensen, C. K. (2009). Introduction to research in education (8th Edition). Belmont, CA: Wadsworth.

Alebaikan, R., \& Troudi, S. (2010). Blended learning in Saudi universities: Challenges and perspectives. ALT-J, Research in Learning Technology, 18 (1), $49-59$.

Al-Khatiri, F. (2015). Beyond the classroom walls: Edmodo in Saudi secondary school EFL instruction, attitudes and challenges. English Language Teaching, 8 (1), 189-204.

Almaini, Y. (2013). Issues in integrating information technology in learning and teaching EFL: The Saudi experience. Merit Search Journal of Education and Review, 1 (5), 107-111.

Al-Naibi, I., Al-Jabri, M., \& Al-Kalbani, I. (2018). Promoting students' paragraph writing using Edmodo: An action research. TOJET: The Turkish Online Journal of Educational Technology, 17 (1), 130143.

Alonso, F., López, G., Manrique, D., \& Viñes, J. M. (2005). An instructional model for web-based e-learning education with a blended learning process approach. British Journal of Educational Technology, 36, 217-235.

Barnawi, O. (2009). The Internet and EFL college instruction: A small-scale study of EFL college teachers' reactions. International Journal of Instructional Technology and Distance Learning, 6 (6), 47-64.

Bonk, C. J., \& Graham, C. R. (Eds.). (2005). Handbook of blended learning: Global perspectives, local designs. San Francisco: Pfeiffer Publishing.

Brown, H. D. (2004). Language assessment, principle and classroom practice. New York: Longman.

Brandon, L. (2002). Writing connection. New York: Houghton Mifflin Company.

Chambliss, D. F., \& Schutt, R. K. (2013). Making sense of the social world, methods of investigation (4th edition). Thousand Oaks, CA: SAGE Publication. 
Qismullah YUSUF, Yunisrina Qismullah YUSUF, Nira ERDIANA, Arif Rizky PRATAMA. Engaging with EDMODO to teach English writing of narrative texts to EFL students

\section{PROBLEMS \\ OF EDUCATION \\ IN THE $21^{\text {st }}$ CENTURY Vol. 76, No. 3, 2018}

348

Charoenwet, S., \& Christensen, A. (2016). The effect of Edmodo learning network on students' perception, self-regulated learning behaviours and learning performance. Proceedings of the 10th international multi-conference on society, cybernetics and informatics (ICMSI 2016) (pp. 297300). July 5 - 8, 2016, Orlando, Florida.

Delacruz, S. (2013). Online reading response using Edmodo. The Florida Reading Journal, 49 (2), 9-12. Dudeney, G., \& Hockly, N. (2007). How to teach English with technology. Harlow: Longman.

Egbert, J., \& Hanson-Smith, E. (Eds.). (1999). CALL environments: Research, practice, and critical issues. Alexandria, VA: TESOL

Fakhir, Z. (2015). The impact of Blended Learning on the achievement of the English language students and their attitudes towards it (Master's thesis). Middle East University, Amman.

Foddy, W. (1993). Constructing questions for interviews and questionnaires: Theory and practice in social research. Cambridge: Cambridge University Press.

Hatch, E. \& Lazaraton, A. (1991). The research manual: Design and statistics for applied linguistics. New York: Newbury House.

Grosseck, G. (2009). To use or not to use web 2.0 in higher education? Procedia Social and Behavioral Sciences, 1, 478-482.

Haygood, E., Garner, R., \& Johnson, S. (2012). Blended learning: Using Web 2.0S to enhance classroom instruction. Retrieved on 28 February 2017 from http://www.cehs.ohio.edu/.

Heaton, J. B. (1988). Writing English language tests. New York: Longman Inc.

Janpho, J., Chaeturat, C., Multa, D., Harnburut, K., \& Kwangsawad, T. (2010). Enhancing English writing skill by using online social network Edmodo. Journal of Education Mahasarakhan University, 4 (4), 707-712.

Jacob, A. M. (2011). Benefits and barriers to the hybridization of schools. Journal of Education Policy, Planning, and Administration, 1 (10), 61-82.

Joutsenvirta, T., \& Myyry, L. (2010). Blended Learning in Finland. Helsinki: Faculty of Social Sciences at the University of Helsinki.

Kamarullah., Yusuf, Q., \& Meutia, C. I. (2016). The use of Quipper School with Computer-Assisted Language Learning (CALL) for teaching ESL writing. Proceedings of the First Reciprocal Graduate Research Symposium between University Pendidikan Sultan Idris and Syiah Kuala University (pp. 166-178). February 26-28, Tanjong Malim, Perak, Malaysia.

Kongchan, C. (2012). How a non-digital-native teacher makes use of Edmodo. Proceedings of the International Conference ICT for Language Learning 5th Edition. Retrieved on 23 February 2017 from https://conference.pixel-online.net/conferences/ICT4LL2012/common/download/Paper_ pdf/90-IBT18-FP-Kongchan-ICT2012.pdf.

Kongchan, C. (2013). How Edmodo and Google docs can change traditional classrooms. Proceedings of the European Conference on Language Learning 2013. Retrieved 23 February 2017 from http:// iafor.org/archives/offprints/ecll2013-offprints/ECLL2013_0442.pdf.

Lara, V.D. (2013). The improvement of writing based on a genre approach through the use of an e-learning platform (Master's Thesis). University of Veracruz, Veracruz.

Latham, B. (2007). Sampling: What is it? Retrieved on 24 February 2017 from http://webpages.acs.ttu. edu/rlatham/Coursework/5377(Quant))/Sampling_Methodology_Paper.pdf.

Muslem, A., Yusuf, Y. Q., \& Juliana, R. (2018). Perceptions and barriers to ICT use among English teachers in Indonesia. Teaching English with Technology, 18 (1), 3-23.

Motiwalla, L. F. (2007). Mobile learning: A framework and evaluation. Computers \& Education, 49 (3), 581-596.

Noviana, O., Rufinus, A., \& Bunau, E. (2015). The effective use of Edmodo in writing a narrative text in senior high school. Jurnal Pendidikan dan Pembelajaran, 4 (11), 3-17.

Purnawarman, P., Susilawati, S., \& Sundayana, W. (2016). The use of Edmodo in teaching writing in a blended learning setting. Indonesian Journal of Applied Linguistics, 5 (2), 242-252.

Riffe, D., Lacy, S. \& Fico, F. G. (2005). Analyzing media messages: Using quantitative content analysis in research. Mahwah, NJ: Lawrence Erlbaum.

Sari, D. F., \& Yusuf, Y. Q. (2009). The role of attitudes and identity from nonnative speakers of English towards English accents. English as International Language Journal, 4, 110-128.

Silviyanti, T. M. (2014). Looking into EFL students' perceptions in listening by using English movie videos on YouTube. Studies in English Language and Education, 1 (1), 42-58.

Silviyanti, T. M., \& Yusuf, Y. Q. (2015). EFL teachers' perceptions on using ICT in their teaching: To use or to reject? Teaching English with Technology, 15 (4), 29-43. 
Qismullah YUSUF, Yunisrina Qismullah YUSUF, Nira ERDIANA, Arif Rizky PRATAMA. Engaging with EDMODO to teach English writing of narrative texts to EFL students

Singh, H., \& Reed, C. (2001). A white paper: Achieving success with blended learning. Lexington, MA: Centra Software.

Spika, P. (2002). Approximately "real world" learning with the Hybrid Model. Teaching with Technology Today, 8(6). Retrieved on 24 February 2017 from http://www.uwsa.edu/ttt/articles/spilka.htm.

Stockwell, G. (2008). Investigating learner preparedness for and usage patterns of mobile learning. ReCALL, 20 (3), 253-270.

Stroud, C. (2010). Edmodo: A white paper. Retrieved on 24 February 2017 from https://internal.masd. k12.wi.us/cms/0.Classroom.Connections/Documents/Edmodo-White-Paper.pdf.

Tsou, W., Wang, W., \& Tzeng, Y. (2006). Applying a multimedia storytelling website in foreign language learning. Computers and Education, 47(1), 17-28.

Thorne, K. (2003). Blended Learning: How to integrate online and traditional learning. London: Kogan.

Van Dam, N., \& Andrade, M. (2005). Supercharge your Blended Learning. Portland: Chief Learning Officer.

Westwood, P. (2008). What teachers need to know about reading and writing difficulties. Victoria: Acer Press.

Wesson, R., McKenzie, S., \& Bangay, S. (2015). Anytime and anywhere: A case study for Blended Learning. Washington D.C.: Educause.

Received: February 07, 2018

Accepted: May 30, 2018

\begin{tabular}{l} 
PROBLEMS \\
OF EDUCATION \\
IN THE 21 $1^{\text {st }}$ CENTURY \\
Vol. 76, No. 3, 2018 \\
\hline 349
\end{tabular}

Received: February 07,2018

Accepted: May 30, 2018

\begin{tabular}{|c|c|}
\hline Qismullah Yusuf & $\begin{array}{l}\text { Ph.D. (Doctor of Philosophy in Education), senior lecturer, English Educa- } \\
\text { tion Department, Faculty of Teacher Training and Education, Syiah Kuala } \\
\text { University, Darussalam, Banda Aceh 23111, Indonesia. } \\
\text { E-mail: yusufqismullah@gmail.com } \\
\text { Website: http://fsd.unsyiah.ac.id/qismullah.yusuf/ }\end{array}$ \\
\hline $\begin{array}{l}\text { Yunisrina Qismullah Yusuf } \\
\text { (Corresponding author) }\end{array}$ & $\begin{array}{l}\text { Ph.D. (Doctor of Philosophy in Phonology), Senior Lecturer, English Educa- } \\
\text { tion Department, Faculty of Teacher Training and Education, Syiah Kuala } \\
\text { University, Darussalam, Banda Aceh 23111, Indonesia. } \\
\text { E-mail: yunisrina.q.yusuf@unsyiah.ac.id } \\
\text { Website: http://fsd.unsyiah.ac.id/yunisrina.q.yusuf/ }\end{array}$ \\
\hline Nira Erdiana & $\begin{array}{l}\text { M.Pd. (Master of English Education), Lecturer, English Education Depart- } \\
\text { ment, Faculty of Teacher Training and Education, Syiah Kuala University, } \\
\text { Darussalam, Banda Aceh 23111, Indonesia. } \\
\text { E-mail: niraerdiana@unsyiah.ac.id } \\
\text { Website: http://fsd.unsyiah.ac.id/niraerdiana/ }\end{array}$ \\
\hline Arif Rizky Pratama & $\begin{array}{l}\text { S.Pd. (Bachelor of English Education), English Tutor, English Education } \\
\text { Department, Faculty of Teacher Training and Education, Syiah Kuala Uni- } \\
\text { versity, Darussalam, Banda Aceh 23111, Indonesia. } \\
\text { E-mail: arif24091994@gmail.com }\end{array}$ \\
\hline
\end{tabular}

